\title{
New Species of Agaricales
}

\author{
Soon Ja Seok ${ }^{1 *}$, Yang Sup Kim², Ki Moon Park', Wan Gyu Kim², Kwan Hee Yoo and In Cheol Park ${ }^{1}$ \\ ${ }^{l}$ National Agrobiodiversity Center, National Academy of Agricultural Science, Rural Development Administration, Suwon 441-707, Korea \\ ${ }^{2}$ Department of Food \& Life Science, Sungkyunkwan University, Suwon 440-746, Korea \\ ${ }^{3}$ Agricultural Microbiology Division, National Academy of Agricultural Science, Rural Development Administration, Suwon 441-707, Korea \\ ${ }^{4}$ Department Biology, Sang-ji University, Wonju 220-702, Korea
}

(Received October 28, 2009. Accepted November 30, 2009)

Clitocybe alboinfundibulliforme sp. nov. is widely distributed in Korea. Volvariella koreana sp. nov. is rarely distributed in Korea. These taxa were occasionally found together at the same place. Both of these species seem to be associated with each other. These two species are fully described and illustrated in this paper.

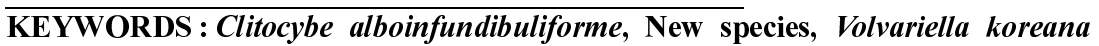

During the investigation of macro-fungi on the Korean peninsula, species of Agaricales, Volvariella sp. and Clitocybe sp., were found to be appearing together, and seems to be associated with each other. Some species of Asterophora lycoperdoide (Bull.) Ditmar or Asterophora parasitica (Bull. ex Pers.) Singer (1986) find on the decaying basidiomes of Russula nigricans (Bull.) Fr.; Lactarius vellereus (Fr.) Fr. and allied species or Syzygospora tumefaciens (Ginns \& Sunhede) Ginns find on Gymnopus dryophilus (Bull.) Murrill and Hodocollybia butyracea f. butyracea (Bull.) Lennox were reported. Not much is known about macro-symbionts among Agarics fungi, except symbiosis between Gomphidius roseus (Fr.) Fr. and Suillus bovinus (Pers.) Roussel. Symbiosis between Volvariella sp. and Clitocybe sp. has not been reported. In this paper, the principal diagnostic features of Volvariella sp. were described and illustrated according to Orton (1974) and Bigelow (1982), viz. the color of the pileus and volva, the morphology of the volva (especially Volvariella), the microscopic features of pileipellis, stipitipellis, spores, basidia, cystidia and their habitat. In the following descriptions, color names are given in quotations and color notations, e. g. 4A2 8F4, are from those of Kornerup and Wanscher (1978).

The collections cited here are all deposited in the herbarium of the Herbarium Conservation Center of National Academy of Agricultural Science (HCCN).

\section{Clitocybe alboinfundibuliforme sp. nov. (Korean name: Bidanteolkkalddaegibeoseos)}

Pileus 25 54 mm latus, infundibuliformis, fere cavus ad basis, siccus, glaber, albidus, demum ivory grayish-orange,

\footnotetext{
$\overline{\text { *Corresponding author }}<$ E-mail : mycena@korea.kr $>$
}

hygrophanus, ad marginem involutus, caro tenuissima, albida, odor nullus. Lamellae decurrentes, distante, albideae demum pallido brunneae. intervenoseae. Stipes 28 $48 \mathrm{~mm}$ longus, 3 6 $\mathrm{mm}$ crassus, equals, Crepido tumidae, ad pileus concolor, cavus. Sporae $4 \sim 6.3 \times 3.2 \sim 4 \mu \mathrm{m}$, inamyloideae, in cumulo albae. Basidia 19.6 28.4 × 4.2 $5.4 \mu \mathrm{m}$, tetrasporigera. Cystidia inconspicua. Pileipellis subgelatinosa, interspersus cum vesciculose elementus.

Holotypus. Mt. Sookji, Suwon-si Paldal-gu Hwaseodong, Gyeonggi-do, 3 September 1994 (HCCN 01619).

Pileus. 25 54 mm across, uniform, infundibuliform, trumpet-shaped, and generally hollow to the base of the stipe. The pileus is rarely convex and is depressed at the center, with the margin inrolled when young and remaining incurved for a long time. It is somewhat undulate, acute, with a dry, smooth surface. Hygrophanous, it is snow white in color, turning with age to yellowish-white (4A2) to ivory (4B3), orange-white (5A2) to grayish-orange (5B3) in part or towards the margin. In addition, it has a thin context, indistinct odor, and a mild taste.

Lamellae. With a long decurrent shape sometimes reaching to the stipe, and a distant, rarely strongly intervenose character, the lamellae are pure white when young, but change to a very pale brown (10YR7/3-4) to yellow (910YR7/6-8), or yellowish- white (4A2) to ivory (4B3), orange-white (5A2) to grayish-orange (5B3) when old, with smooth edges.

Stipe. $28 \sim 48 \times 3 \sim 6 \mathrm{~mm}$, hollow, cylindrical, tapering toward the base, but at times thickened just at the base. It has a dry, smooth surface, and is pure white in color, turn- 
ing yellowish-white (4A2) to ivory (4B3), orange-white $(5 \mathrm{~A} 2)$ to grayish-orange (5B3), with age.

Microscopic features (Fig. 1). Spore print is white. Spores are $4 \sim 6.3 \times 3.2 \sim 4 \mu \mathrm{m}$, elliptical, tip-shaped, smooth, hyaline, and inamyloid. Basidia are 19.6 28.4 $\times 4.2 \sim 5.4 \mu \mathrm{m}$, clavate, with 4-spores and basal clamp connections. Cheilocystidia and pleurocystidia were not seen. Pileipellis consists of irregularly parallel hyphae $2 \sim 5 \mu \mathrm{m}$ across, slightly gelatinized, generally interspersed with vesicular elements called physalids $28.5 \sim 35.8 \times 16.4 \sim 20.5 \mu \mathrm{m}$, which are also found in the apex of the stipe; generally septa with a clamp connection.

Holotype. Mt. Sookji, Suwon-si Paldal-gu Hwaseodong, Gyeonggi-do, 3 September 1994 (HCCN 01619).

Habit and Habitat. Summer to fall, grouped or gregarious, rarely scattered on the rich humus soils or the piles of fallen leaves in hardwood or in mixed woods and sometimes co-associated with Volvariella sp. (Fig. 3A C).

Specimens examined. Mt. Sookji, Suwon-si Paldal-gu Hwaseo-dong, Gyeonggi-do, 3 September 1994 (Holotype, HCCN 01619); Mt. Halla, Jeju-si, Jeju-do, 19 July 1997 (6477A); Mt. Yeogi, Suwon-si Paldal-gu Hwaseo-dong Gyeonggi-do, 8 August 1997 (6494A); Mt. Seolak, Bukmyeon, Inje-gun, Gangwon-do, 6 September 1997 (6583A); Mt. Chiack, Socho-myeon, Wonju-si, Gangwon-do, 16 July 1998 (7172A); Mt. Yeogi, Suwon-si Paldal-gu Hwaseo-

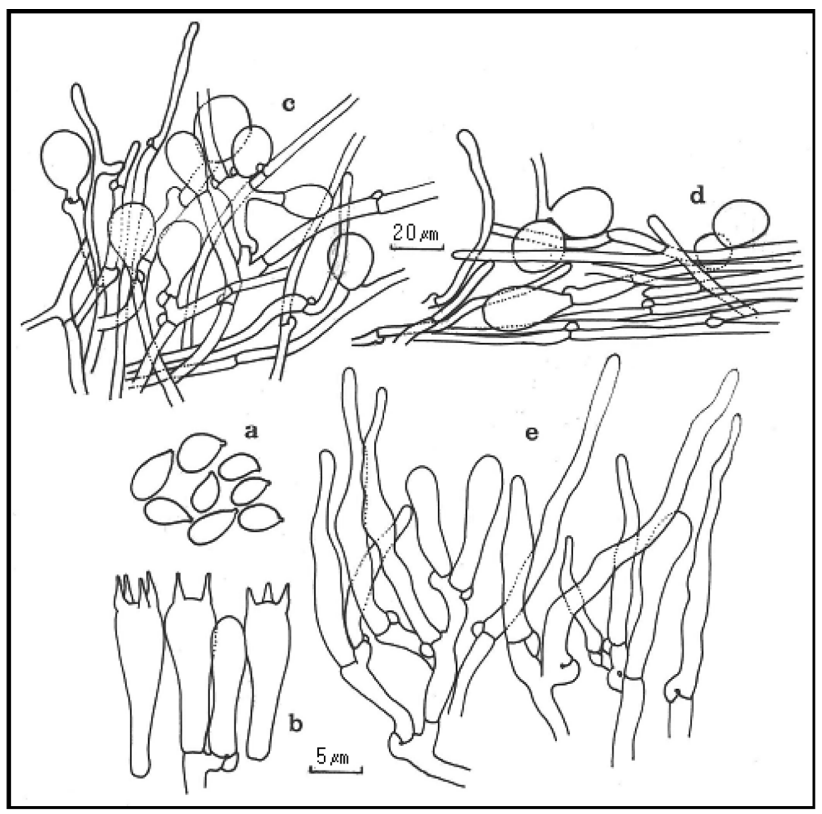

Fig. 1. Clitocybe alboinfundibuliforme. a, spores $(\times 1000)$, b, basidia $(\times 1000)$, c, pileipellis $(\times 400)$, f, stipitipellis $(\times 400)$, e, cheilocystidia $(\times 1000)$. dong Gyeonggi-do, 16 July 1998 (7196A); Temp. Naewon, Habuk-myeon, Yangsan-si, Gyeongsangnam-do, 3 August 2000 (8392A); Mt. Yongin-si Cheoingu Mohyeon-myeon, Gyeonggi-do, 27 August 2000 (8525A); Dalter Park, Yangjae-dong, Seocho-gu, Seoul, 31 August 2000 (8548A); Mt. Chiack, Socho-myeon, Wonju-si, Gangwon-do, 11 October 2000 (8880A). Mt. Yeogi, Suwon-si Paldal-gu Hwaseodong Gyeonggi-do, 19 August 2002 (10620A).

Remarks. The specimens found at Gyeonggi-do, Gangwon-do, Gyeongsangnam-do and Jeju Island tend to be a common species and widely distributed in Korean peninsula. They are usually found having the gregarious or grouped habit of carphophores and sometimes co-associated with Volvariella sp.. This new taxon belongs to section Bulluliferae, subgenus Cystoclitus, and is similar to Clitocybe phaeophthalma (Pers.) Kuyper in having the pileipellis and stipitipellis consisting of the peculiar vesicular elements. The latter differs from the former in having a convex pileus with a depressed center, with a lardaceous, grey-beige pileal surface, and may be associated with Volvariella sp.. This species also differs from other similar white species of Clitocybe by having pileipellis composed of irregularly parallel hyphae, with scattered vesicular elements called physalids.

This taxon is well characterized by the entirely pure white carpophores, infundibuliform in shape and generally hollow to the base of the stipe, with long decurrent lamellae and also associated with Volvariella sp. (Fig. 3E $\mathrm{H}$ ).

\section{Volvariella koreana sp. nov. (Korean name: Kkald- daegibidanteolbeoseos)}

Pileus 25 45 mm latus, conicus vel conius-campanulatus, dein convexus vel planus, ad centrum umbonatus, superficies primum griseo-brunneus, demum rufulus-griseus, appressus fibrillosus, ad marginem appendiculatus, carnosus ad centrum, albida, odor inconspicuus. Lamellae liberae, confertae, albideae demum roseae incarnatae. ad aciem albidae fimbriatae, lamellulis intermixtae. Stipe 50 $57 \mathrm{~mm}$ longus, ad apicem 2 2.7 mm crassus, aequalis vel sursum attenuatus, innatus fibrillosus, cavus. Volva membranacea, primum griseo-brunneus, demum pallidus ochracea. Sporae 4.8 5.1 $\times 3.2 \sim 3.7 \mu \mathrm{m}$, inamyloideae, in cumulo sordidus. Basidia 18.6 26 $\times 7.4 \sim 8.4 \mu \mathrm{m}$, tetrasporigera. Pleurocystidia $42 \sim 53 \times 12 \sim 23.3 \mu \mathrm{m}$, fusoideo ventricosa vel lageniforma, ad apicis subcapitatus. Cheilocystidia 35.3 $45.6 \times 9 \sim 17 \mu \mathrm{m}$, fusoideo ventricosa vel sublageniforma, ad apicis subcapitatus vel aliquando flexuosus, tenuis, fasciatus. Hyphae non fibulatoriae.

Holotypus. Mt. Sookji, Suwon-si Paldal-gu Hwaseodong, Gyeonggi-do, 3 September 1994 (HCCN 01615).

Pileus. Basidiocarps small. Pileus are $25 \sim 45 \mathrm{~mm}$ wide, 
at first conical to conico-campanulate, then plano-convex to plane, usually papillar to broadly umbonate at center. It is never depressed in the center. The surface varies in shades from grayish-white to whitish, sometimes orangegray (6B2) to flesh (6B3) or grayish brown (7-8C-D3-4), grayish-brown (7-8E3) to dark brown $(7-8 \mathrm{~F} 3-4)$ at center when young, and then reddish-grey $(8 \mathrm{~B} 2)$ to a dull red, paler towards the margin, often darker to pale grayish-buff in center, with a radially grayish, appressed fibrillose or densely felted hairy surface, the margin sometimes appendiculate and projecting beyond the lamellae.

Context are White, fleshy, thick at center, thin towards the margin, odor slightly similar to Pleurotus ostreatus (Jacq.) P. Kumm. (fungoid) with a mild.

Lamellae are free, subcrowded to crowded, white, later sordid incarnate, with a thin, white edge; fimbriate to flocculose. Lamellulae are 1-or 2-tiered.

Stipe are 50 57 $\times 2 \sim 2.7 \mathrm{~mm}$ (at apex), cylindrical, somewhat equal or attenuated upwards, but slightly thickened at the base. When young, it is whitish in color, discoloring to a pale fawn later in life. At the apex, it is finely pruinose, entirely innately fibrillose striate, but silky-pubescent near the base. Volva is membranous, rather thick, white and then later becoming very pale cream to pale ochraceous buff, with a two or three-lobed margin and felted outer surface.

Microscopic features (Fig. 2). Spore print is sordid. Spores are $4.8 \sim 5.1 \times 3.2 \sim 3.7 \mu \mathrm{m}$, smooth, ellipsoid to ovoid, and slightly thick-walled. Basidia are 18.6 26× 7.4 8.4 $\mu \mathrm{m}$, normal, and four-spored. Pleurocystidia are $42 \sim 53 \times 12 \sim 23.3 \mu \mathrm{m}$, fusoid-ventricose to lageniform, thinwalled with subcapitate to a broadly obtuse apex. Cheilocystidia are 35.3 45.6 $\times 9 \sim 17 \mu \mathrm{m}$, sublageniform, subcapitate or fusiform-ventricose with a long neck, sometimes flexuous, thin-walled, and bundled. Pileipellis of pileus is cylindrical to filamentous, $56 \sim 123 \times 11.3 \sim 18 \mu \mathrm{m}$, and thinwalled without a clamp-connection.

Holotype. Mt. Sookji, Suwon-si Paldal-gu Hwaseo-dong, Gyeonggi-do 3, September 1994 (HCCN 01615).

Habit and Habitat. Solitary to scattered, near or among the fruit-bodies of $C$. alboinfundibuliforme on the rich humus soils, or well decayed fallen leaves in hardwood or in mixed woods (Fig. 3D).

Specimens examined. Mt. Sookji, Suwon-si Paldal-gu Hwaseo-dong, Gyeonggi-do, 3 September 1994 (Holotype, HCCN 01615); Park Dalter, Yangjae-dong, Seochogu, Seoul, 31 August 2000 (8549A); Mt. Yeogi, Suwon-si Gwonseon-gu Seodun-dong, Gyeonggi-do, 19 August 2002 (10621A).

Remarks. The first specimen of this taxon was found

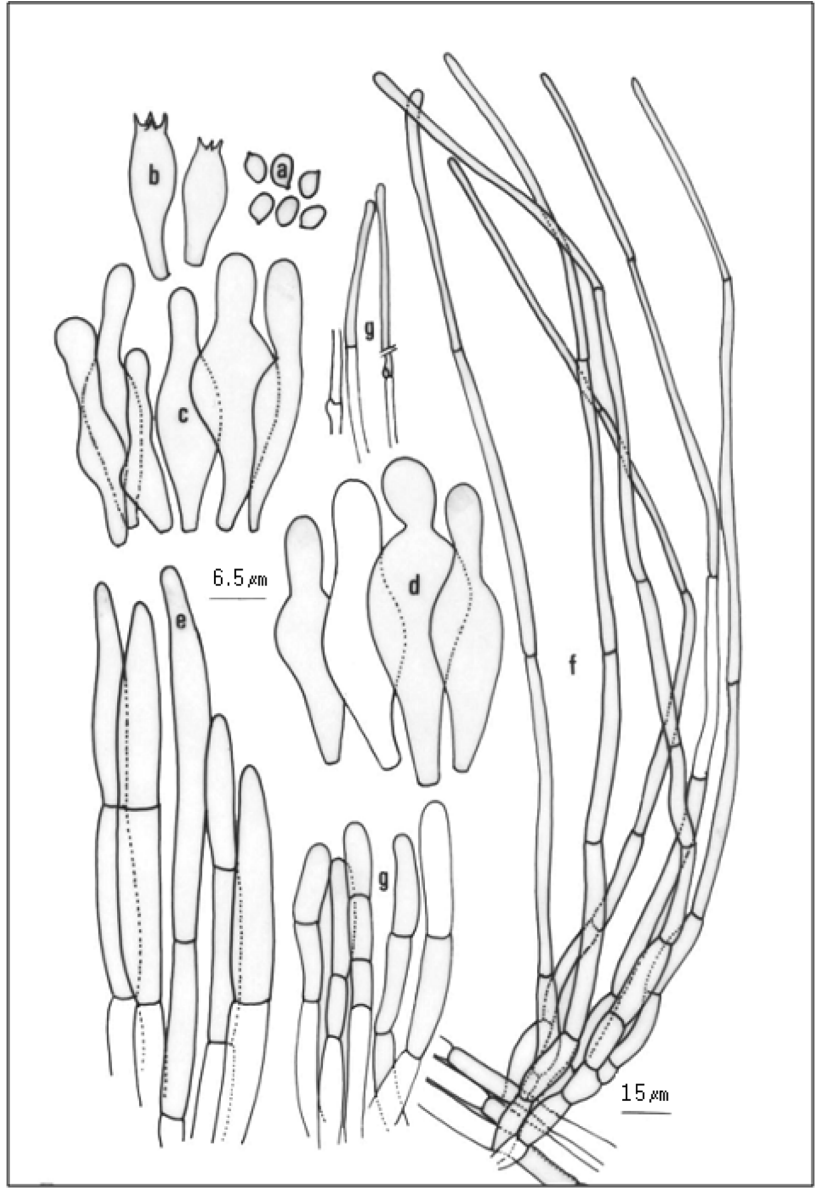

Fig. 2. Volvariella koreana. a, spores $(\times 1000)$ b, basidia $(\times 1000), \mathrm{c}$, cheilocystidia $(\times 1000), \mathrm{d}$, pleurocystidia $(\times 1000)$, e, pileipellis $(\times 400), f$, hairs at the base of stipe $(\times 400)$, g, marginal cells of volva $(\times 400)$.

among the Clitocybe sp. on the rich humus soils under the mixed forests of Quercus sp., Acacia sp. and Pinus rigiiteada, Mt. Sookji in Suwon, 11 August 1994. More specimens were added from Mt. Seonun, and Park Dalter, Seoul. This taxon is well characterized by its specialized habitat among or near Clitocybe sp., the whitish or greyish brown to dark brown pileus, usually papillar to broadly umbonate at center and smaller spores. They coincide well with some species belonging to stirp Taylori according to Orton (1986). This species can also be confused with other small species of Volvariella, such as Volvariella murinella (Quél.) M.M. Moser, Volvariella caesiotincta P.D. Orton, Volvariella taylorii (Berk. \& Broome) Singer, and Volvariella surrecta (Knapp) Singer. But Volvariella murinella (Quél.) M.M. Moser differ from the present species by the white-grey or light beige pileus without a distinct papillar to umbonate at center, are narrow, have elongated to subcylindrical spores and a different ecology. V. caesiotincta is characterized having cheilocystidia with conspicuous rostrum, like to forked apical projection, and grows on rotten wood. Also, V. taylori differs 
A

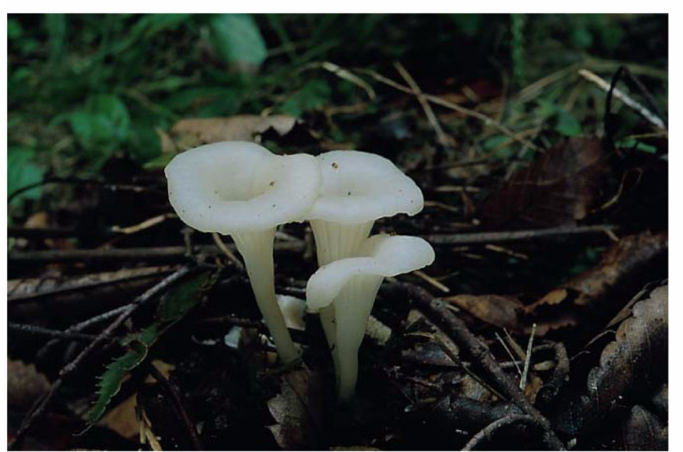

C

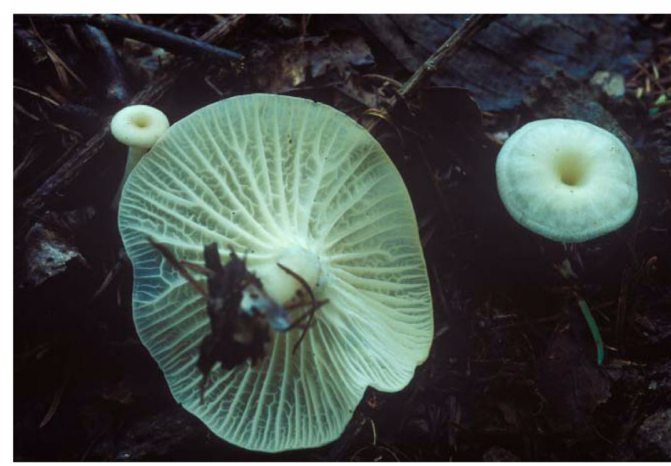

E

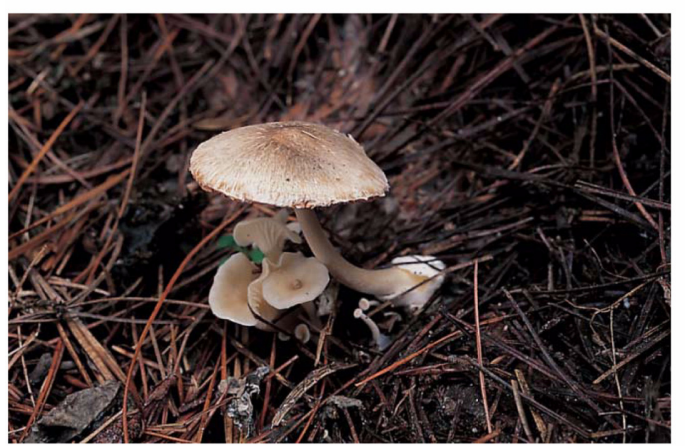

G

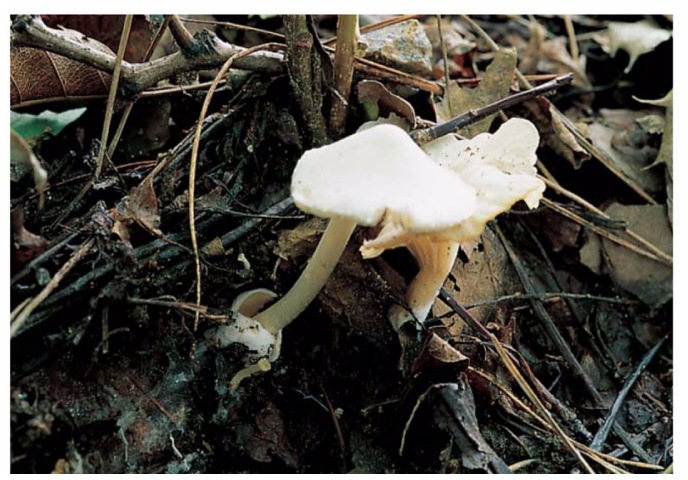

B

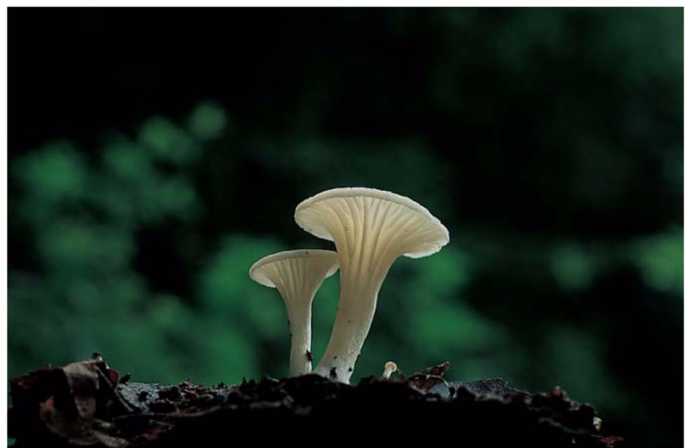

D

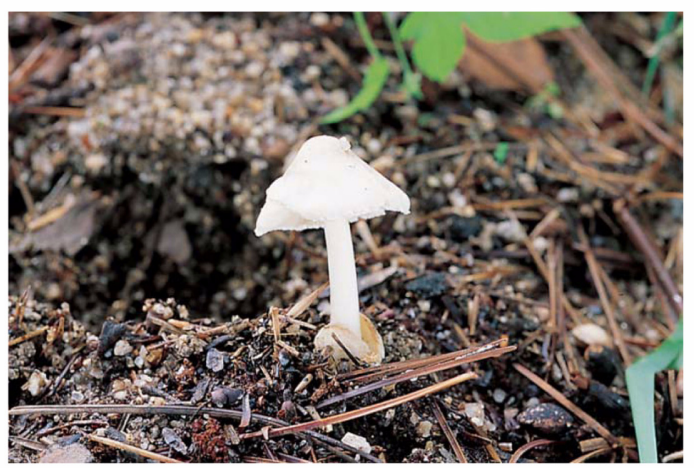

F

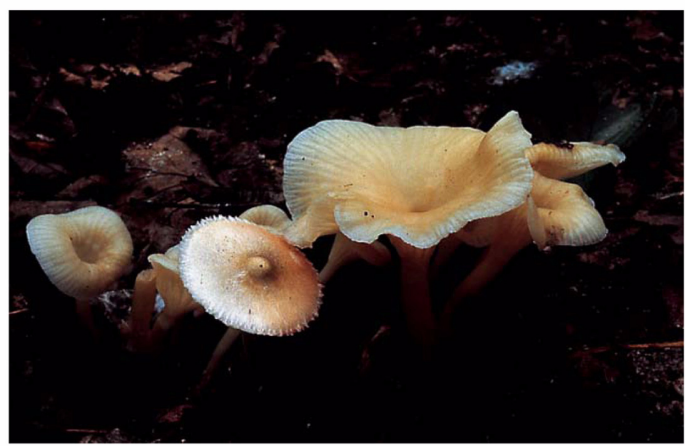

H

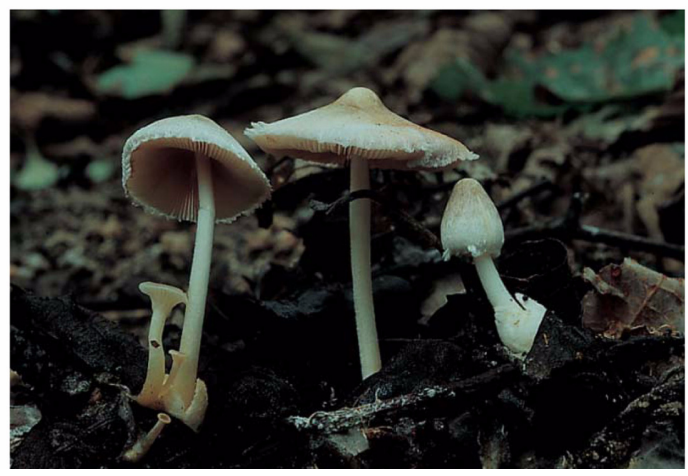

Fig. 3. Carphophores of $C$. alboinfundibuliforme and V. koreana. A C, C. alboinfundibuliforme (HCCN 01619); D, V. koreana (HCCN 01615); E H, carphophores of these two fungi growing together.

from this taxon by having slightly larger basidiocarps with a brown to ochraceous grey volva and a pale buff grey to grey pileus, without a prominent papilar to umbonate at center. And the basidiocarps of $V$. surrecta are typically found growing on the dead fruit-bodies of C. nebularius, characterized by the smooth stipe surface. 


\section{References}

Bas, C., Kuyper, Th. W., Noordeloos, M. E. and Vellinga, E. C. 1990. Flora Agaricina Neerlandica 2. Balkema, Rotterdam.

Bigelow, H. E. 1982. North American Species of Clitocybe: Part I, pp. 1-280. J. Cramer, Vaduz.

Boekhout, T. and Enderle, M. 1986. Volvariella gloiocephala (DC.: Fr.) Boekhout \& Enderle comb. nov. Beitr. Kennt. Pilze Mitteleuropas 2:77-80.

Breitenbach, J. and Kränzlin, F. 1991. Fungi of Switzerland: A Contribution to the Knowledge of the Fungal Flora of Switzerland, Vol. 3, pp. 148-169. Mykologia, Lucerne.

Breitenbach, J. and Kräanzlin, F. 1995. Fungi of Switzerland: A Contribution to the Knowledge of the Fungal Flora of Switzerland, Vol. 4, pp. 34-139. Mykologia, Lucerne.

Harmaja, H. 1969. The genus Clitocybe (Agaricales) in Fennos- candia. Karstenia. 10:5-121.

Hongo, T. 1963. Notes on Japanese Larger Fungi (16). J. Jpn. Bot. 38:233-240.

Kornerup, A. and Wanscher, J. H. 1978. Methuen Handbook of Colour, 3rd edition. Eyre Methuen Ltd., London.

Orton, P. D. 1974. The European species of Vovariella Spegazini. Bull. Mens. Soc. Linn. Lyon 43:311-321.

Orton, P. D. 1986. Pluteaceae: Pluteus \& Volvariella. Royal Botanic Garden, Edinburgh.

Shaffer, R. L. 1957. Volvariella in North America. Mycologia 49:545-579.

Shaffer, R. L. 1962. Synonyms, new combinations, and new species in Volvariella (Agaricales). Mycologia 54:563-572.

Singer, R. 1986. The Agaricales in Modern Taxonomy, 4th edition. Koeltz Scientific Books, Koenigstein. 